\title{
Effect of Anthocyanins Supplementation on Serum IGFBP-4 Fragments and Glycemic Control in Patients with Fasting Hyperglycemia: A Randomized Controlled Trial
}

This article was published in the following Dove Press journal:

Diabetes, Metabolic Syndrome and Obesity: Targets and Therapy

\author{
Liping Yang ${ }^{1,2}$ \\ Zhaomin Liu ${ }^{2}$ \\ Wenhua Ling ${ }^{2}$ \\ Li Wang' \\ Changyi Wang' \\ Jianping $\mathrm{Ma}^{\prime}$ \\ Xiaolin Peng' \\ Jianying Chen $\mathbb{D}^{3}$ \\ 'Center for Chronic Disease Control, \\ Nanshan, Shenzhen, People's Republic of \\ China; ${ }^{2}$ Guangdong Provincial Key \\ Laboratory of Food, Nutrition and \\ Health, Department of Nutrition, School \\ of Public Health, Sun Yat-sen University, \\ Guangzhou, People's Republic of China; \\ ${ }^{3}$ Internal Medicine Department, BaiYun \\ Hospital, GuangZhou, GuangDong \\ Province, People's Republic of China
}

Background: Insulin-like growth factor binding protein-4 (IGFBP-4) fragments have been shown to be associated with cardiometabolic diseases. Anthocyanins as a subgroup of natural polyphenols could have benefits on treating cardiometabolic diseases. The aim of this study was to examine the effects of purified anthocyanins on serum IGFBP-4 fragments and glycemic control in patients with fasting hyperglycemia.

Methods: A set of 121 participants with elevated fasting glucose $(\geq 5.6 \mathrm{mmol} / \mathrm{L})$, who were originally randomly assigned to anthocyanins (320 mg/day) or placebo groups, were included in this study. Serum IGFBP-4 fragments, fasting and postload glucose, insulin, and C-peptide after a three-hour oral glucose tolerance test (OGTT) were measured at baseline and at the end of 12 weeks.

Results: Compared with placebo, anthocyanins increased serum IGFBP-4 fragments (net change $8.33 \mathrm{ng} / \mathrm{mL}, 95 \%$ CI $[1.2,15.47], p=0.023)$ and decreased fasting glucose $(-0.4$ $\mathrm{mmol} / \mathrm{L}[-0.71,-0.1], p=0.01), 2$-hour C-peptide $(-1.02 \mathrm{ng} / \mathrm{mL}[-1.99,-0.04], p=0.041)$ and the 3-hour area under the curve (AUC) of C-peptide $(-2.19[-4.11,-0.27], p=0.026)$. No other significant difference in parameters for glycemic control and insulin resistance was observed.

Conclusion: Anthocyanins supplementation for 12 weeks improved serum IGFBP-4 fragments and decreased fasting glucose and postload C-peptide in patients with fasting hyperglycemia. Further studies are needed to confirm our findings and clarify the potential mechanism.

Trial Registration: ClinicalTrials.gov, NCT02689765. Registered on 6 February 2016, https://clinicaltrials.gov/ct2/show/NCT02689765.

Keywords: IGFBP-4 fragments, anthocyanin, oral glucose tolerance test, insulin resistance, C-peptide

\section{Introduction}

The epidemic of diabetes mellitus has been a major health threat both in China and worldwide. ${ }^{1}$ In china, diabetes accounts for 116 million adults in 2019 . $^{2}$ Over 90\% of diabetes mellitus are type 2 diabetes mellitus (T2DM). The main pathological basis of T2DM is hyperglycemia and insulin resistance. Insulin is known to be the only hormone in our body that can decrease blood glucose, but another class of hormones named insulin-like growth factors (IGFs, IGF-I and IGF-II), which are
Correspondence: Liping Yang Center for Chronic Disease Control, NanShan, ShenZhen 518000, People's Republic of China

Tel +86-755-26403300

Email yanglp6@mail2.sysu.edu.cn
Diabetes, Metabolic Syndrome and Obesity: Targets and Therapy 2020:13 3395-3404

submit your manuscript (c) (i) (5) 2020 Yang et al. This work is published and licensed by Dove Medical Press Limited. The full terms of this license are available at https://www.dovepress.com/terms.php BY NC and incorporate the Creative Commons Attribution - Non Commercial (unported, v3.0) License (http:///creativecommons.org/licenses/by-nc/3.0/). By accessing the work you hereby accept the Terms. Non-commercial uses of the work are permitted without any further permission from Dove Medical Press Limited, provided the work is properly attributed. For permission for commercial use of this work, please see paragraphs 4.2 and 5 of our Terms (https://www.dovepress.com/terms.php). 
structurally and functionally similar to insulin, may have the same effect. The IGF system also includes the family of insulin-like growth factor binding proteins (IGFBPs). Among these IGFBPs, IGFBP-4 is the smallest member and may serve to restrain or limit the activity of IGF-I. ${ }^{3}$ It can be hydrolyzed into fragments by pregnancy-associated plasma protein-A (PAPP-A) ${ }^{4,5}$ thereby regulating IGFs availability.

The IGF axis is implicated in metabolic and vascular disorders, and has been proposed as a potential therapeutic target for insulin resistance and T2DM. ${ }^{6,7}$ During recent decades, there has been growing interest in the relation between T2DM and the newly identified IGFBP-4 fragments. A cross-sectional study found that IGFBP-4 fragments were lower in newly diagnosed and well-controlled T2DM patients than in healthy controls and were associated with cardiovascular disease risk factors. ${ }^{8}$ However, the role of circulating IGFBP-4 fragments in the progression of T2DM remains unclear, and few interventional studies have focused on IGFBP-4 fragments.

Anthocyanins are a subgroup of polyphenols that are widespread in colorful edible plants. There are inconsistent results concerning the antidiabetic effect of anthocyanin or anthocyanin-rich extracts in interventional studies. ${ }^{9,10} \mathrm{We}$ have reported the favorable effects of purified anthocyanins on the lipid profile in patients with prediabetes or newly-diagnosed diabetes. ${ }^{11}$ Nonetheless, we did not observe significant alterations in fasting glucose in the overall subjects. Since the participants varied, with differences in pathogenesis and metabolic characteristics, such as impaired fasting glucose (IFG) and impaired glucose tolerance (IGT), ${ }^{12,13}$ we proposed a study that only included subjects characterized by newly-diagnosed fasting hyperglycemia to investigate the effect of anthocyanins on serum IGFBP-4 fragments, and to explore the correlations between IGFBP-4 fragments and glucose metabolism.

\section{Subjects and Methods Study Design and Participants}

This study was performed as a 12-week CONSORTcompliant, randomized controlled trial (RCT) registered with ClinicalTrials.gov (Identifier: NCT02689765). The original study was conducted in Guangzhou, China in 2016, and the details of the study design and methods have been described elsewhere. ${ }^{11}$ Participants with prediabetes or newly diagnosed diabetes (fasting glucose $\geq 5$. 6 $\mathrm{mmol} / \mathrm{L}$ or 2 -hour glucose $\geq 7.8 \mathrm{mmol} / \mathrm{L}$ or glycated hemoglobin Alc $(\mathrm{HbAlc}) \geq 5.7 \mathrm{mmol} / \mathrm{mol})$ were recruited for the trial. The exclusion criteria were as follows: 1) a history of diabetes or hypoglycemic agents; 2) pregnant or lactating women; and 3) acute or chronic infectious disease, thyroid disease, glucocorticoid use, polycystic ovarian syndrome, traumatic injuries or surgeries. In the present study, we excluded participants with isolated postprandial hyperglycemia, and included a subset of participants with fasting hyperglycemia, which was defined as elevated fasting glucose $(\geq 5.6 \mathrm{mmol} / \mathrm{L})$, referring to the American Diabetes Association criteria for the diagnosis of IFG. ${ }^{14}$

Eligible participants were randomly assigned to receive either anthocyanins or placebo treatment. The allocation sequence was determined by computer-generated randomnumbers. Investigators, participants and laboratory technicians were blinded to the assignment until the completion of the data collection and analysis. The daily anthocyanin capsules were described in the previous trials of our laboratory, ${ }^{15,16}$ and contained $320 \mathrm{mg}$ of 17 different anthocyanins, which were mainly purified from natural bilberry and blackcurrant, with most delphinidin3-O-glucosides and cyanidin-3-O-glucosides, and pullulan and maltodextrin as excipients. The detailed ingredients were described in a previous trial from our laboratory. ${ }^{17}$ Participants in the control group were instructed to consume identically packaged placebo capsules, which only contained the same excipients with the same color. The Ethics Committee of Sun Yat-Sen University approved this study, and all participants provided a signed informed consent form.

\section{Data Collection}

Participants underwent a standardized 3-hour $75 \mathrm{~g}$ oral glucose tolerance test (OGTT) following a 10-hour overnight fast. Venous blood samples were obtained at 0,30 , 60,120 and 180 minutes for the determination of serum glucose, insulin and C-peptide levels. Specimens were aliquoted and stored at $-80^{\circ} \mathrm{C}$ until measurement.

Anthropometric measures were assessed by trained staff using calibrated scales with the participants shoeless and wearing light clothing. The same staff measured blood pressure in the right arm using a standard mercury sphygmomanometer. All participants completed a face-to-face questionnaire that included sociodemographic data, medical history, use of medication, and lifestyle factors including habitual food intakes and physical activities. 
Participants were asked to provide a three-day dietary record, which was used to estimate dietary nutrient intakes at baseline and after 12 weeks of the study according to the Chinese Food Composition Table. During the whole intervention, participants were asked to avoid consuming anthocyanin-rich foods, such as berries and grapes. They were also asked to maintain their usual dietary habits and physical activities. Anthocyanin or placebo capsules were given to the participants after randomization. All the participants were asked to attend periodic interviews every 2 weeks, and compliance was evaluated by counting their remaining capsules. When compliance was less than $80 \%$ of the scheduled capsules, subjects were excluded from the trial.

\section{Laboratory Measurements}

Serum IGFBP-4 fragments were measured using an ELISA kit and a solid-phase two-site enzyme immunoassay (Mercodia, Uppsala, Sweden). The average intra- and interassay coefficients of variation (CVs) for IGFBP-4 fragments were $3.3 \%$ and $4.6 \%$, respectively. Serum glucose was measured by the glucose oxidase method. HbA1c was assayed by cation exchange high-pressure liquid chromatography (HPLC) (Bio-Rad Laboratories, California, USA). Insulin and C-peptide were determined by electrochemical luminescence (Roche Diagnostics, Indianapolis, USA). Fasting blood samples were also collected to measure triglycerides, total cholesterol, low-density lipoprotein (LDL) cholesterol and high-density lipoprotein (HDL) cholesterol with an automated analyzer. Apolipoprotein A-1 (apo A-1) and apolipoprotein B (apo B) levels were measured with the nephelometric method.

\section{Calculations for Insulin Sensitivity}

Areas under the curve (AUCs) of the 3-hour OGTT for glucose, insulin, and C-peptide were calculated according to the trapezoidal rule. The homeostasis model assessment of insulin resistance (HOMA-IR) and $\beta$-cell function (HOMA- $\beta$ ) were calculated based on fasting glucose and insulin concentrations. ${ }^{18}$ The index of hepatic insulin clearance was calculated by the AUC of the C-peptide-to-insulin ratio. ${ }^{19}$ The insulin secretion function of $\beta$-cells was measured by the insulinogenic index $\left(\Delta \operatorname{Insulin}_{30 \mathrm{~min}-0 \mathrm{~min} /} \Delta \mathrm{Glucose}_{30 \mathrm{~min}-0 \mathrm{~min}}\right){ }^{20}$ The fasting and postload C-peptide indexes (CPIs) after oral glucose ingestion were calculated as the C-peptide-to-glucose ratio. $^{21}$

Dynamic measures of glucose and insulin homeostasis:

HOMA-IR $=$ (fasting insulin $[\mu \mathrm{U} / \mathrm{mL}] \times$ fasting glucose $[\mathrm{mmol} / \mathrm{L}]) / 22.5)$.
HOMA- $\beta=20 \times$ fasting insulin $[\mu \mathrm{U} / \mathrm{mL}] /($ fasting glucose $[\mathrm{mmol} / \mathrm{L}]-3.5)$.

Insulinogenic index $=\left(\right.$ Insulin $_{30 \mathrm{~min}^{-}}$

Insulin $\left._{0 \mathrm{~min}}\right) /\left(\right.$ Glucose $_{30 \mathrm{~min}}-$ Glucose $\left._{0 \mathrm{~min}}\right)$.

Insulin clearance $=$ AUC C-peptide/AUC Insulin.

Fasting and postprandial $\mathrm{CPI}=100 \times \mathrm{C}$-peptide $[\mathrm{ng} / \mathrm{mL}] /$ glucose $[\mathrm{mg} / \mathrm{dL}]$.

\section{Statistical Analysis}

Statistical analyses were performed with SPSS 22.0 (IBM Inc., Chicago, IL, USA) and R 3.5.3 (R Foundation, Vienna, Austria). The data for this study were analyzed using the perprotocol (PP) data set. Continuous variables were expressed as the mean $\pm \mathrm{SD}$. Categorical variables were expressed as numbers (percentages) and were compared using the chisquare test. Baseline demographics, dietary intakes and physical activities were compared between the two groups by Student's $t$-test to assess their baseline comparability.

The differences between the before- and after- intervention measurements were analyzed using a paired $t$-test. Both the independent Student's $t$-test and a linear mixed model (ANCOVA) were used to compare the differences in the net changes between the two groups, with false discovery rate (FDR) correction for multiple comparisons. The covariates adjusted in the mixed model included baseline value, age, sex, and medications for blood pressure and lipids. Pearson correlation coefficients $(r)$ were used to determine the association between the changes in IGFBP-4 fragments and glucose metabolism markers.

\section{Results}

\section{Subject Characteristics at Baseline and Follow-Up}

A total of 121 subjects with elevated fasting glucose were included in this study, and 104 subjects (54 in the anthocyanin group and 50 in the control group) successfully completed the 12-week treatment and attended the follow-up visits (Supplemental Figure 1). At least $90 \%$ of the participants in each group consumed $89 \%$ of the supplements provided, and compliance did not significantly differ between the two groups (one subject in each group was excluded).

Subjects in the two intervention groups were comparable in demographics and anthropometric markers, such as age, sex, body weight, waist circumference, and dietary intake of total energy and food groups (Table 1). In addition, baseline values of parameters for glycemic control, insulin sensitivity, and lipids 
were similar between the two groups (data will be submitted on request). After 12 weeks of intervention, no significant difference between the two groups was observed either in the changes in anthropometric, hepatic and renal function or inflammatory markers (Supplemental Table 1), or in the changes in dietary nutrients during the intervention (Supplemental Table 2).

\section{Effects of Anthocyanins on IGFBP-4 Fragments and Metabolic Markers}

Serum IGFBP-4 fragment levels were significantly decreased in the placebo group $(-4.83 \mathrm{ng} / \mathrm{mL}, 95 \% \mathrm{CI}$ $[-9.56,-1.02], p=0.045)$ but tended to be increased in the anthocyanins group $(3.51 \mathrm{ng} / \mathrm{mL}[-1.89,8.91]$, $p=0.198$ ), resulting in a relative significant difference between the anthocyanins and placebo groups (with a net change of $8.33 \mathrm{ng} / \mathrm{mL}, 95 \%$ CI [1.2, 15.47], $p=0.023)$ (Figure 1, Table 2). After adjusting for potential confounders in the ANCOVA model, the difference between the two groups remained significant. A similar marginally significant change in IGFBP-4 fragments was also observed in the mixed ANCOVA model among the overall subjects of the primary trial (data not shown).

Fasting glucose levels were decreased in the anthocyanins group $(-0.27 \mathrm{mmol} / \mathrm{L}[-0.5,-0.04], p=0.024)$, while no significant change was observed in the control group $(0.13 \mathrm{mmol} / \mathrm{L}[-0.06,0.33], p=0.178)$, and

Table I Baseline Characteristics of the Study Participants

\begin{tabular}{|c|c|c|c|}
\hline & Anthocyanins $(n=56)$ & Placebo $(n=65)$ & $P$ \\
\hline Age (years) & $61.27 \pm 8.36$ & $60.88 \pm 6.97$ & 0.78 \\
\hline $\operatorname{Sex}(M / F)$ & $19 / 37$ & $23 / 42$ & 1 \\
\hline Education & & & 0.85 \\
\hline Primary school & $5(8.9 \%)$ & $7(10.8 \%)$ & \\
\hline Middle school & $33(58.9 \%)$ & $40(61.5 \%)$ & \\
\hline College & $18(32.1 \%)$ & $18(27.7 \%)$ & \\
\hline Occupation & & & 0.19 \\
\hline Professionals & $30(53.6 \%)$ & $33(50.8 \%)$ & \\
\hline Laborers & $23(41.1 \%)$ & $22(33.8 \%)$ & \\
\hline Others & $3(5.4 \%)$ & $10(15.4 \%)$ & \\
\hline Current smoking & II(19.6\%) & $6(9.2 \%)$ & 0.12 \\
\hline Alcohol drinking & $3(5.4 \%)$ & $3(4.6 \%)$ & 1 \\
\hline \multicolumn{4}{|l|}{ Anthropometrics } \\
\hline Weight (kg) & $64.2 \pm 12.49$ & $63.23 \pm 10.57$ & 0.64 \\
\hline BMI (kg/m2) & $24.92 \pm 3.05$ & $25.11 \pm 3.45$ & 0.75 \\
\hline Waist circumference $(\mathrm{cm})$ & $88.9 \pm 9.29$ & $88.2 \pm 8.89$ & 0.67 \\
\hline Hip circumference $(\mathrm{cm})$ & $97.3 \pm 7.66$ & $96.33 \pm 8.74$ & 0.52 \\
\hline Waist/hip ratio & $0.91 \pm 0.05$ & $0.9 \pm 0.05$ & 0.36 \\
\hline $\mathrm{SBP}(\mathrm{mmHg})$ & $133.24 \pm 16.65$ & $133.04 \pm 20.04$ & 0.95 \\
\hline $\mathrm{DBP}(\mathrm{mmHg})$ & $78.91 \pm 10.45$ & $78.14 \pm 9.27$ & 0.67 \\
\hline \multicolumn{4}{|l|}{ Dietary intake } \\
\hline Total energy (kcal/d) & $|824.12 \pm 758.3|$ & $1878.48 \pm 708.86$ & 0.69 \\
\hline Grains and cereals (g/d) & $375.23 \pm 230.83$ & $404.67 \pm 160.2$ & 0.41 \\
\hline Vegetables (g/d) & $339.64 \pm 228.83$ & $343.61 \pm 197.6$ & 0.92 \\
\hline Fruits (g/d) & $94.15 \pm 201.43$ & $84.01 \pm 121.1$ & 0.73 \\
\hline Anthocyanins (mg/d) & $10.55 \pm 7.6$ & $10.61 \pm 4.92$ & 0.96 \\
\hline Sports & & & 0.58 \\
\hline I 3 times/week & $21(\%)$ & $28(\%)$ & \\
\hline 4 7times/week & $35(\%)$ & $37(\%)$ & \\
\hline
\end{tabular}

Notes: Data are presented as the mean \pm standard deviation for continuous variables and $\mathrm{n}(\%)$ for categorical variables. $P$ value was for the differences between the two groups, compared by independent samples $t$-test.

Abbreviations: BMI, body mass index; SBP, systolic blood pressure; DBP, diastolic blood pressure. 

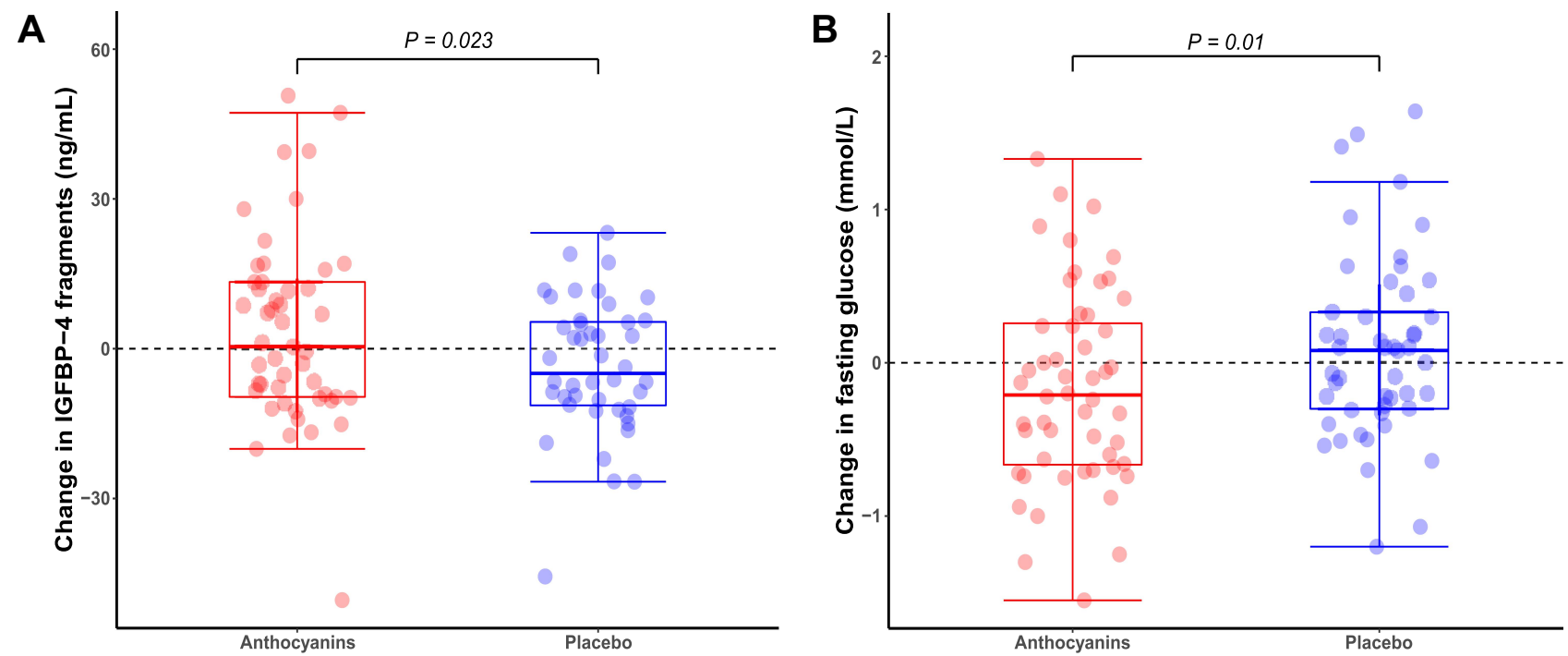

Figure I Changes in IGFBP-4 fragments and fasting glucose after 12 weeks of treatment with anthocyanins or placebo. (A) Changes in IGFBP-4 fragments, (B) changes in fasting glucose.

a significant difference (net change $-0.4 \mathrm{mmol} / \mathrm{L}[-0.71$, $-0.1], p=0.01$ ) between the two groups was observed (Figure 1, Table 2). Significant differences were also observed in the net changes in postload 2-hour C-peptide $(-1.02 \mathrm{ng} / \mathrm{mL}[-1.99,-0.04], p=0.041)$ and the 3-hour AUC for C-peptide $(-2.19[-4.11,-0.27]$, $p=0.026$ ) (Figure 2, Table 2). The adjusted mixed model showed similar significant differences in fasting glucose and postload C-peptide, except for an additional significance of the 2-hour CPI $(-0.48[-1.1,0.14], p=0.028)$. No other significant difference between the anthocyanins and placebo groups was observed in the markers for glycemic control and insulin sensitivity.

For lipid metabolism, anthocyanins significantly decreased LDL cholesterol $(-0.28 \mathrm{mmol} / \mathrm{L} \quad[-0.55$, $-0.02], p=0.035)$ and apo B $(-0.09 \mathrm{~g} / \mathrm{L}[-0.17,-0.01]$, $p=0.025$ ) after the 12 -week treatment, but no other significant difference was observed in lipid profile (Supplemental Table 3). A similar pattern was observed among the overall subjects in the primary study (data not shown).

\section{Correlation Between the Changes in IGFBP-4 Fragments and Glucose Metabolism Parameters}

The change in IGFBP-4 fragments was inversely correlated with postload 2-hour glucose $(r=-0.42, p=0.005)$ and 2-hour C-peptide $(r=-0.33, p=0.03)$ as well as the insulinogenic index $(r=-0.31, p=0.04)$ in the placebo group (Supplemental Figure 2). In contrast, no significant association was observed between the change in IGFBP-4 fragments and 2-hour glucose $(r=0.02, p=0.88), 2$-hour C-peptide $(r=-0.05, p=0.72)$ and the insulinogenic index $(r=-0.16, p=0.29)$ in the anthocyanins group.

\section{Discussion}

To our knowledge, this is the first interventional study to examine the effect of purified anthocyanins on serum IGFBP-4 fragments, an important regulatory protein of the IGF system. The current study showed that 12-week anthocyanins supplementation at $320 \mathrm{mg} / \mathrm{d}$ is effective for reducing fasting glucose, 2-hour C-peptide and the AUC of C-peptide during a 3-hour OGTT, and tends to increase serum IGFBP-4 fragment levels in patients with untreated fasting hyperglycemia.

The effect on IGFBP-4 fragments may provide a novel biochemical basis for the use of anthocyanins. To better understand the clinical implications of our findings, the complex PAPP-A-IGFBP-IGF axis should be elucidated. The PAPP-A-generated IGFBP-4 fragments reflect PAPP-A enzymatic activity and provide a novel cardiac risk marker. ${ }^{22,23}$ IGFBP-4 bidirectionally modulates the interaction with IGFs and their receptors. Both the N-terminus and C-terminus segments of IGFBP-4 can mask or block the binding of IGF-I to its receptor, thereby controlling the activity and distribution of IGF-I. ${ }^{24}$ When IGFBP-4 is cleaved, IGF-I is released from IGFBP-4 and becomes 
Table 2 Changes in Glucose Metabolism Parameters After 12 Weeks of Treatment with Anthocyanins or Placebo in Hyperglycemic Patients

\begin{tabular}{|c|c|c|c|c|c|c|c|}
\hline & \multicolumn{2}{|c|}{ Anthocyanins $(n=54)$} & \multicolumn{2}{|c|}{ Placebo $(n=50)$} & \multirow[t]{2}{*}{ Net Change $(95 \% \mathrm{Cl})$} & \multirow[t]{2}{*}{$\boldsymbol{P}_{\text {t-test }}$} & \multirow[t]{2}{*}{$P_{\text {ANCOVA }}$} \\
\hline & Baseline & I 2 Weeks & Baseline & 12 Weeks & & & \\
\hline IGFBP4 (ng/mL) & $64.44 \pm 19.29$ & $67.95 \pm 17.09$ & $65.52 \pm 25.15$ & $60.69 \pm 19.69 *$ & $8.33(1.2,15.47))^{\dagger \ddagger}$ & 0.023 & 0.003 \\
\hline \multicolumn{8}{|l|}{ Glycemic control } \\
\hline Hemoglobin Alc (\%) & $6.24 \pm 0.62$ & $5.9 \pm 0.5^{*}$ & $6.09 \pm 0.57$ & $5.89 \pm 0.59 *$ & $-0.13(-0.26,0)$ & 0.058 & 0.151 \\
\hline Fasting glucose (mmol/L) & $6.56 \pm 0.66$ & $6.29 \pm 0.74 *$ & $6.37 \pm 0.54$ & $6.5 \pm 0.74$ & $-0.4(-0.71,-0.1)^{\dagger \ddagger}$ & 0.010 & 0.040 \\
\hline 2-h glucose (mmol/L) & $10.6 \pm 3.58$ & $11.15 \pm 3.25$ & $9.43 \pm 3.45$ & $10.35 \pm 3.33^{*}$ & $-0.37(-1.45,0.71)$ & 0.499 & 0.697 \\
\hline Fasting insulin $(\mu \mathrm{U} / \mathrm{mL})$ & $11.92 \pm 7.11$ & $11.05 \pm 5.86$ & $12.57 \pm 5.45$ & $12.16 \pm 6.78$ & $-0.68(-2.4 \mathrm{I}, 1.05)$ & 0.437 & 0.441 \\
\hline 2-h insulin $(\mu \mathrm{U} / \mathrm{mL})$ & $92.14 \pm 61.6$ & $98.1 \pm 55.97$ & $83.42 \pm 57.3$ & $107.66 \pm\left. 78.3\right|^{*}$ & $-16.38(-36.07,3.3)$ & 0.102 & 0.121 \\
\hline Fasting C-peptide (ng/mL) & $2.64 \pm 1.06$ & $2.52 \pm 0.89$ & $2.61 \pm 1.12$ & $2.6 I \pm 0.95$ & $-0.14(-0.4,0.11)$ & 0.260 & 0.325 \\
\hline 2-h C-peptide (ng/mL) & $11.45 \pm 3.53$ & $11.72 \pm 3.18$ & $10.92 \pm 3.7$ & $12.35 \pm 4.26 *$ & $-1.02(-1.99,-0.04)^{\dagger \ddagger}$ & 0.041 & 0.035 \\
\hline \multicolumn{8}{|l|}{ Insulin sensitivity } \\
\hline HOMA-IR & $3.49 \pm 2.26$ & $3.12 \pm 1.7$ & $3.62 \pm 1.8$ & $3.58 \pm 2.2$ & $-0.37(-0.98,0.25)$ & 0.238 & 0.188 \\
\hline HOMA- $\beta$ & $80.2 \pm 44.67$ & $82.51 \pm 44.6$ & $87.4 \pm 33.52$ & $82.17 \pm 41.83$ & $7.54(-4.43,19.5)$ & 0.214 & 0.369 \\
\hline AUC Glucose & $30.76 \pm 7.01$ & $32.08 \pm 6.34$ & $28.5 I \pm 6.47$ & $30.43 \pm 6^{*}$ & $-0.49(-2.7, \mid .7 \mathrm{I})$ & 0.658 & 0.613 \\
\hline AUC Insulin & $210.24 \pm 121.22$ & $224.21 \pm 107.89$ & $218.3 \pm 124.53$ & $268.78 \pm 164.15^{*}$ & $-34.38(-7 I .26,2.5 I)$ & 0.067 & 0.056 \\
\hline AUC C-peptide & $26.34 \pm 7.42$ & $26.67 \pm 6.23$ & $26.55 \pm 7.76$ & $29.28 \pm 8.77^{*}$ & $-2.19(-4.11,-0.27)$ & 0.026 & 0.011 \\
\hline Insulinogenic index & $9.94 \pm 9$ & $9.94 \pm 7.17$ & $11.06 \pm 8.85$ & $11.83 \pm 8.15$ & $-0.77(-3.04,1.51)$ & 0.504 & 0.265 \\
\hline Insulin clearance & $7.23 \pm 2.48$ & $6.62 \pm 2.21 *$ & $6.8 \pm 1.93$ & $6.15 \pm 1.84 *$ & $0.03(-0.53,0.6)$ & 0.904 & 0.446 \\
\hline Fasting CPI & $2.24 \pm 0.86$ & $2.23 \pm 0.79$ & $2.25 \pm 0.88$ & $2.23 \pm 0.76$ & $0.01(-0.16,0.19)$ & 0.906 & 0.897 \\
\hline 2-h CPI & $6.57 \pm 2.35$ & $6.2 \pm 1.97$ & $6.99 \pm 2.86$ & $7.1 \pm 2.87$ & $-0.48(-1.1,0.14)^{\ddagger}$ & 0.126 & 0.028 \\
\hline
\end{tabular}

Notes: Data are presented as the mean \pm standard deviation. $* P<0.05$ by paired $t$-test for the comparison of the difference between baseline and 12 weeks. ${ }^{\dagger} P<0.05$ by independent samples $t$-test for the net change difference between the two groups. ${ }^{\ddagger} p<0.05$ by ANCOVA for the net change difference between the two groups after adjusting for baseline values, age, sex, blood pressure and lipid medications.

Abbreviations: AUC, area under the curve; HOMA, homeostasis model assessment.

available to activate its receptor. ${ }^{25,26}$ At this point, the increase in IGFBP-4 fragments in the current study may reflect an increase in IGF-I action. Epidemiological studies have suggested that lower circulating IGF-I was associated with $\mathrm{T}_{2} \mathrm{DM}^{27}$ and higher all-cause mortality, ${ }^{28}$ while higher IGF-I conferred a reduced risk of coronary artery disease. ${ }^{29}$ However, other studies showed opposing relationships between IGF-I and cardiometabolic risks. ${ }^{30-32}$ Similarly, high levels of IGFBP-4 fragments were found to be associated with an increased risk of cardiac events in patients with symptoms of myocardial ischemia. ${ }^{33}$ The possible reason could be that local IGF-I in coronary atherosclerosis stimulates vascular smooth muscle cell proliferation and releases inflammatory factors leading to vulnerable plaques. ${ }^{34,35}$ Due to the complexity of IGF system function, clinical implications vary in different disease populations. A large prospective study found that the association between free IGF-I and T2DM varied by insulin levels, ${ }^{36}$ and indicated an inverse association limited to subjects with higher levels of insulin. Thus, data from individual patients with specific conditions, such as those in this study, are required to reach firmer conclusions.
A recent interventional study indicated that blackcurrant anthocyanin increased the concentration of cyclic glycine-proline (cGP), a metabolite of IGF-I, to exert neuroprotective benefits in patients with Parkinson's disease. ${ }^{37}$ To some sense, the increase in IGF-I metabolite response to anthocyanin treatment is consistent with the increase in IGFBP-4 fragments in the current study. An animal study suggested that the increase in circulating IGF-I could promote resistance to IGF-I-mediated glucose reduction. ${ }^{38}$ Due to the presence of binding proteins and possible IGF-I resistance, the levels of circulating IGF-I do not reflect its bioactive function.

In this study, we observed a relative increase in IGFBP-4 fragments (12.8\%) along with the glucoselowering effect of anthocyanins. Mechanistic studies have previously demonstrated the antidiabetic effect of anthocyanins. ${ }^{39}$ Our previous meta-analysis conclusively revealed that anthocyanins could decrease fasting glucose in cardiometabolic diseases (standardized mean difference: $-0.31[-0.59,-0.04]) .{ }^{40} \mathrm{~A}$ recent meta-analysis also demonstrated that anthocyanins improved glycemic control, especially in studies with intervention duration $>8$ 


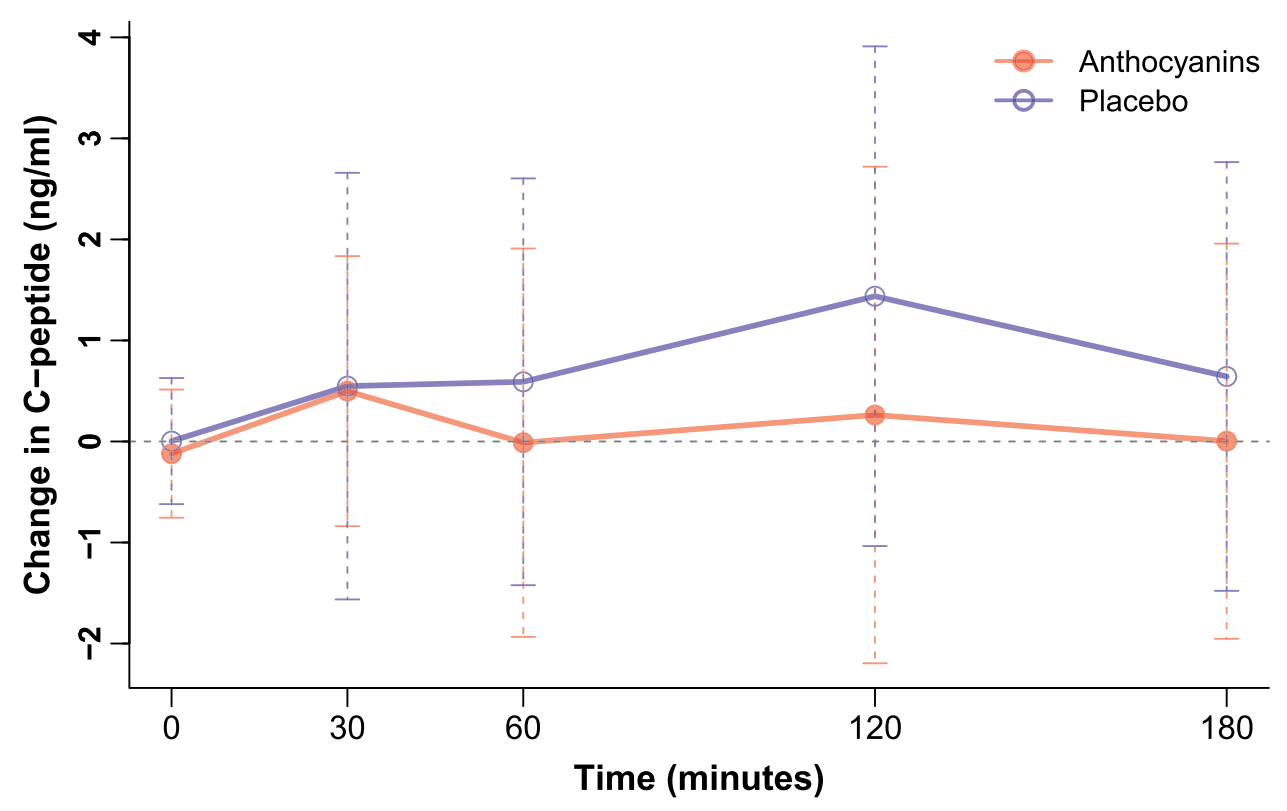

Figure 2 Changes in C-peptide following a 3-hour oral glucose tolerance test. The changes of 2-hour C-peptide and the area under the curve for C-peptide were decreased in anthocyanins group compared with placebo.

weeks and anthocyanin doses $>300 \mathrm{mg} / \mathrm{d}^{41}$ An early in vitro study indicated that high levels of glucose modulate IGFBP-4 stability and increase IGFBP-4 proteolytic activity, thereby enhancing IGF-I availability to its receptors. ${ }^{42}$ IGF-I could elicit an insulin-like hypoglycemic response by producing a similar suppression of glucose production and increasing glucose uptake. ${ }^{43}$ The combined improvement of IGFBP-4 fragments and fasting glucose in this study may suggest a protective effect of anthocyanins against the development of T2DM. The relation between IGF system and glucose metabolism is of interest and requires further investigation.

According to the correlation analyses, decreased IGFBP4 fragments were negatively correlated with the increase in postload glucose and C-peptide in the controls, while anthocyanins eliminated these correlations by increasing IGFBP-4 fragments and decreasing postload C-peptide. C-peptide is cosecreted with insulin and cannot be cleared by the liver; therefore, the serum C-peptide level may provide a more stable measure of endogenous insulin secretion. ${ }^{44}$ In addition, C-peptide has lower within-subject and between-subject variation than insulin, ${ }^{45}$ which is consistent with our data. C-peptide also has an insulinomimetic effect and interacts synergistically with insulin. ${ }^{46}$

Case-control studies for T2DM suggested that high levels of fasting or postprandial C-peptide were associated with insulin resistance, ${ }^{47}$ increased carotid artery intima-media thickness (CIMT), ${ }^{48}$ and increased risk of all-cause and cardiovascular mortality. ${ }^{49}$ Another earlier study suggested that a C-peptide-based index was more closely related to T2DM than an insulin-based index..$^{50}$ In the current study, a decrease was observed in another parameter associated with endogenous insulin secretion, the 2 -hour $\mathrm{CPI},{ }^{51}$ which appears to better predict pancreatic $\beta$-cell area than fasting measures, such as the HOMA index. ${ }^{52}$ Taken together, the decreases in postprandial C-peptide and CPI in this study might suggest a potential effect of anthocyanins that prevents the progression of insulin resistance.

The current study has some limitations. First, the concentration of IGF-I was not measured. Since the majority of circulating IGF-I is bound to IGFBPs, the measurable IGF-I in circulation is largely physiologically inactive and does not reflect its bioactivity. ${ }^{53}$ Second, we measured only IGFBP-4 fragments rather than full-length IGFBP-4. Some influences on the precision of detection should be considered, such as low concentration, high molecular weight, and interference by formation of complexes with other proteins. ${ }^{54}$ In contrast, the detection of IGFBP-4 fragments is reliable, and the concentrations of the fragments present in the circulation are similar to those of intact IGFBP-4. ${ }^{55}$ Finally, this study represents a subgroup analysis from a randomized trial and therefore can be interpreted as a controlled prospective cohort study with observational research evidence. Nevertheless, the baseline characteristics and most metabolic parameters were distributed equally between the two groups, which represents the achievement of first-level evidence in this study. We also 
adjusted the baseline value of all parameters and other possible confounders that were not considered in the random process. Additionally, the changes in IGFBP-4 fragments within the subgroup were consistent with and representative of the results in the primary study. Nonetheless, additional long-term trials specifically designed for hyperglycemic patients are needed to confirm our findings.

\section{Conclusion}

In patients with fasting hyperglycemia, intervention with $320 \mathrm{mg} / \mathrm{d}$ of purified anthocyanins for 12 weeks improved serum IGFBP-4 fragments, fasting glucose, and postprandial C-peptide levels. The findings of this study provide new evidence for clinical applications using the IGF system, such as IGFBP-4 fragments, to evaluate the prevention and treatment of T2DM. Further studies are needed to clarify the potential mechanism and should include complete and precise measurement of the IGF system and its metabolites to elucidate their variation in the treatment of type 2 diabetes.

\section{Abbreviations}

T2DM, type 2 diabetes; RCT, randomized controlled trial; IFG, impaired fasting glucose; IGT, impaired glucose tolerance; OGTT, oral glucose tolerance test; AUC, area under the curve; IGF, insulin-like growth factor; IGFBP, insulin-like growth factor binding protein; PAPP-A, pregnancy-associated plasma protein-A; HOMA-IR, homeostasis model assessment of insulin resistance; HOMA- $\beta$, homeostasis model assessment of $\beta$-cell function; CPI, C-peptide index; FDR, false discovery rate; HbAlc, glycated hemoglobin A1c; LDL, low-density lipoprotein; HDL, high-density lipoprotein; apoA-1, apolipoprotein A-1; apo B, apolipoprotein B; CIMT, carotid artery intimamedia thickness.

\section{Data Sharing Statement}

The deidentified data presented in this study are available from the corresponding author upon reasonable request.

\section{Acknowledgments}

The authors would like to thank the participants for their time and enthusiasm and all of the medical staff who facilitated this study.

\section{Author Contributions}

All authors made a significant contribution to the work reported, whether that is in the conception, study design, execution, acquisition of data, analysis and interpretation, or in all these areas; took part in drafting, revising or critically reviewing the article; gave final approval of the version to be published; have agreed on the journal to which the article has been submitted; and agree to be accountable for all aspects of the work.

\section{Funding}

This study was supported by the Key Project of National Natural Science Foundation of China (grant number 81730090) and the Health Technology Project of NanShan, ShenZhen (grant number 2019034).

\section{Disclosure}

The authors have no possible conflicts of interest associated with this work.

\section{References}

1. Zheng Y, Ley SH, Hu FB. Global aetiology and epidemiology of type 2 diabetes mellitus and its complications. Nat Rev Endocrinol. 2018;14(2):88-98. doi:10.1038/nrendo.2017.151

2. Saeedi P, Petersohn I, Salpea P, et al. Global and regional diabetes prevalence estimates for 2019 and projections for 2030 and 2045: results from the International Diabetes Federation Diabetes Atlas, 9 (th) edition. Diabetes Res Clin Pract. 2019;157:107843. doi:10.1016/ j.diabres.2019.107843

3. Fowlkes J, Freemark M. Evidence for a novel insulin-like growth factor (IGF)-dependent protease regulating IGF-binding protein-4 in dermal fibroblasts. Endocrinology. 1992;131(5):2071-2076. doi:10.1210/endo.131.5.1385096

4. Bach LA. Insulin-like growth factor binding proteins 4-6. Best Pract Res Clin Endocrinol Metab. 2015;29(5):713-722. doi:10.1016/j.beem.2015.06.002

5. Mazerbourg S, Callebaut I, Zapf J, Mohan S, Overgaard M, Monget P. Up date on IGFBP-4: regulation of IGFBP-4 levels and functions, in vitro and in vivo. Growth Hormone IGF Res. 2004;14 (2):71-84. doi:10.1016/j.ghir.2003.10.002

6. Lewitt MS, Dent MS, Hall K. The Insulin-Like Growth Factor System in Obesity, Insulin Resistance and Type 2 Diabetes Mellitus. J Clin Med. 2014;3(4):1561-1574. doi:10.3390/jcm3041561

7. de Kort S, Simons C, van den Brandt PA, et al. Diabetes mellitus, genetic variants in the insulin-like growth factor pathway and colorectal cancer risk. Int J Cancer. 2019. doi:10.1002/ijc.32365

8. Hjortebjerg R, Laugesen E, Hoyem P, et al. The IGF system in patients with type 2 diabetes: associations with markers of cardiovascular target organ damage. Eur $j$ Endocrinol. 2017;176 (5):521-531. doi:10.1530/EJE-16-0940

9. Curtis PJ, van der Velpen V, Berends L, et al. Blueberries improve biomarkers of cardiometabolic function in participants with metabolic syndrome-results from a 6-month, double-blind, randomized controlled trial. Am J Clin Nutr. 2019;109(6):1535-1545. doi:10.1093/ajen/nqy380

10. Mirfeizi M, Mehdizadeh Tourzani Z, Mirfeizi SZ, Asghari Jafarabadi M, Rezvani HR, Afzali M. Controlling type 2 diabetes mellitus with herbal medicines: A triple-blind randomized clinical trial of efficacy and safety. $J$ Diabetes. 2016;8(5):647-656. doi:10.1111/1753-0407.12342

11. Yang L, Ling W, Yang Y, et al. Role of Purified Anthocyanins in Improving Cardiometabolic Risk Factors in Chinese Men and Women with Prediabetes or Early Untreated Diabetes-A Randomized Controlled Trial. Nutrients. 2017;9. 
12. Tripathy D, Carlsson M, Almgren $P$, et al. Insulin secretion and insulin sensitivity in relation to glucose tolerance: lessons from the Botnia Study. Diabetes. 2000;49(6):975-980. doi:10.2337/ diabetes.49.6.975

13. Hanefeld M, Koehler C, Fuecker K, et al. Insulin secretion and insulin sensitivity pattern is different in isolated impaired glucose tolerance and impaired fasting glucose: the risk factor in Impaired Glucose Tolerance for Atherosclerosis and Diabetes study. Diabetes Care. 2003;26(3):868-874. doi:10.2337/diacare.26.3.868

14. American Diabetes A. Standards of medical care in diabetes-2013. Diabetes Care. 2013;36(Suppl 1):S11-S66.

15. Zhu Y, Ling W, Guo H, et al. Anti-inflammatory effect of purified dietary anthocyanin in adults with hypercholesterolemia: a randomized controlled trial. Nutr Metab Cardiovasc Dis. 2013;23:843-849. doi:10.1016/j.numecd.2012.06.005

16. Zhu Y, Xia M, Yang Y, et al. Purified anthocyanin supplementation improves endothelial function via NO-cGMP activation in hypercholesterolemic individuals. Clin Chem. 2011;57(11):1524-1533. doi:10.1373/clinchem.2011.167361

17. Qin Y, Xia M, Ma J, et al. Anthocyanin supplementation improves serum LDL- and HDL-cholesterol concentrations associated with the inhibition of cholesteryl ester transfer protein in dyslipidemic subjects. Am J Clin Nutr. 2009;90(3):485-492. doi:10.3945/ ajcn.2009.27814

18. Matthews DR, Hosker JP, Rudenski AS, Naylor BA, Treacher DF, Turner RC. Homeostasis model assessment: insulin resistance and beta-cell function from fasting plasma glucose and insulin concentrations in man. Diabetologia. 1985;28(7):412-419. doi:10.1007/BF00280883

19. Burattini R, Di Nardoa F, Casagrande F, Boemi M, Morosini P. Insulin action and secretion in hypertension in the absence of metabolic syndrome: model-based assessment from oral glucose tolerance test. Metabo Clin Exp. 2009;58(1):80-92. doi:10.1016/j. metabol.2008.08.010

20. Abdul-Ghani MA, Jenkinson CP, Richardson DK, Tripathy D, DeFronzo RA. Insulin secretion and action in subjects with impaired fasting glucose and impaired glucose tolerance: results from the Veterans Administration Genetic Epidemiology Study. Diabetes. 2006;55(5):1430-1435. doi:10.2337/db05-1200

21. Okuno Y, Komada H, Sakaguchi K, et al. Postprandial serum C-peptide to plasma glucose concentration ratio correlates with oral glucose tolerance test- and glucose clamp-based disposition indexes. Metabolism. 2013;62(10):1470-1476. doi:10.1016/j. metabol.2013.05.022

22. Conover CA. Key questions and answers about pregnancy-associated plasma protein-A. Trends Endocrinol Metab. 2012;23(5):242-249. doi:10.1016/j.tem.2012.02.008

23. Conover CA, Bale LK, Oxvig C. Targeted Inhibition of Pregnancy-Associated Plasma Protein-A Activity Reduces Atherosclerotic Plaque Burden in Mice. J Cardiovasc Transl Res. 2016;9(1):77-79. doi:10.1007/s12265-015-9666-9

24. Sitar T, Popowicz GM, Siwanowicz I, Huber R, Holak TA. Structural basis for the inhibition of insulin-like growth factors by insulin-like growth factor-binding proteins. Proc Natl Acad Sci U S A. 2006;103 (35):13028-13033. doi:10.1073/pnas.0605652103

25. Resch ZT, Simari RD, Conover CA. Targeted disruption of the pregnancy-associated plasma protein-A gene is associated with diminished smooth muscle cell response to insulin-like growth factor-I and resistance to neointimal hyperplasia after vascular injury. Endocrinology. 2006;147(12):5634-5640. doi:10.1210/ en.2006-0493

26. Byun D, Mohan S, Yoo M, Sexton C, Baylink DJ, Qin X. Pregnancyassociated plasma protein-A accounts for the insulin-like growth factor (IGF)-binding protein-4 (IGFBP-4) proteolytic activity in human pregnancy serum and enhances the mitogenic activity of IGF by degrading IGFBP-4 in vitro. J Clin Endocrinol Metab. 2001;86(2):847-854. doi:10.1210/jcem.86.2.7223
27. Aleidi SM, Shayeb E, Bzour J, et al. Serum level of insulin-like growth factor-I in type 2 diabetic patients: impact of obesity. Horm Mol Biol Clin Investig. 2019;39.

28. Miyake H, Kanazawa I, Sugimoto T. Decreased serum insulin-like growth factor-I level is associated with the increased mortality in type 2 diabetes mellitus. Endocr J. 2016;63(9):811-818. doi:10.1507/ endocrj.EJ16-0076

29. Ruidavets JB, Luc G, Machez E, et al. Effects of insulin-like growth factor 1 in preventing acute coronary syndromes: the PRIME study. Atherosclerosis. 2011;218(2):464-469. doi:10.1016/j. atherosclerosis.2011.05.034

30. van Bunderen CC, van Nieuwpoort IC, van Schoor NM, Deeg DJ, Lips P, Drent ML. The association of serum insulin-like growth factor-I with mortality, cardiovascular disease, and cancer in the elderly: a population-based study. J Clin Endocrinol Metab. 2010;95(10):4616-4624. doi:10.1210/jc.2010-0940

31. Schneider HJ, Klotsche J, Saller B, et al. Associations of age-dependent IGF-I SDS with cardiovascular diseases and risk conditions: cross-sectional study in 6773 primary care patients. Eur j Endocrinol. 2008;158(2):153-161. doi:10.1530/EJE-07-0600

32. Maximus PS. Insulin like growth factor 1 is linked to higher cardiovascular risk score in adults with type 2 diabetes mellitus and chronic kidney disease. Diabetes Metab Syndr. 2019;13 (4):2613-2618. doi:10.1016/j.dsx.2019.07.008

33. Postnikov AB, Smolyanova TI, Kharitonov AV, et al. N-terminal and C-terminal fragments of IGFBP-4 as novel biomarkers for short-term risk assessment of major adverse cardiac events in patients presenting with ischemia. Clin Biochem. 2012;45(7-8):519-524. doi:10.1016/j. clinbiochem.2011.12.030

34. Fierro-Macias AE, Floriano-Sanchez E, Mena-Burciaga VM, et al. Association between IGF system and PAPP-A in coronary atherosclerosis. Arch Cardiol Mex. 2016;86(2):148-156. doi:10.1016/j. acmx.2015.12.006

35. Bayes-Genis A, Conover CA, Schwartz RS. The insulin-like growth factor axis: A review of atherosclerosis and restenosis. Circ Res. 2000;86(2):125-130. doi:10.1161/01.RES.86.2.125

36. Rajpathak SN, He M, Sun Q, et al. Insulin-like growth factor axis and risk of type 2 diabetes in women. Diabetes. 2012;61(9):2248-2254. doi:10.2337/db11-1488

37. Fan D, Alamri Y, Liu K, et al. Supplementation of Blackcurrant Anthocyanins Increased Cyclic Glycine-Proline in the Cerebrospinal Fluid of Parkinson Patients: potential Treatment to Improve Insulin-Like Growth Factor-1 Function. Nutrients. 2018;10.

38. Imrie H, Abbas A, Viswambharan H, et al. Vascular insulin-like growth factor-I resistance and diet-induced obesity. Endocrinology. 2009;150(10):4575-4582. doi:10.1210/en.2008-1641

39. Edirisinghe I, Burton-Freeman B, Seeram NP, Shukkitt-Hale B. Anti-diabetic actions of Berry polyphenols - review on proposed mechanisms of action. J Berry Res. 2016;6:237-250. doi:10.3233/ JBR-160137

40. Yang L, Ling W, Du Z, et al. Effects of Anthocyanins on Cardiometabolic Health: A Systematic Review and Meta-Analysis of Randomized Controlled Trials. Adv Nutr. 2017;8(5):684-693. doi:10.3945/an.116.014852

41. Fallah AA, Sarmast E, Jafari T. Effect of dietary anthocyanins on biomarkers of glycemic control and glucose metabolism: A systematic review and meta-analysis of randomized clinical trials. Food Res Int. 2020;137:109379. doi:10.1016/j.foodres.2020.109379

42. Jacot TA, Clemmons DR. Effect of Glucose on Insulin-Like Growth Factor Binding Protein-4 Proteolysis 1. Endocrinology. 1998;139 (1):44-50. doi:10.1210/endo.139.1.5688

43. Boulware SD, Tamborlane WV, Rennert NJ, Gesundheit N, Sherwin RS. Comparison of the metabolic effects of recombinant human insulin-like growth factor-I and insulin. Dose-response relationships in healthy young and middle-aged adults. J Clin Invest. 1994;93(3):1131-1139. doi:10.1172/JCI117065 
44. Van Cauter E, Mestrez F, Sturis J, Polonsky KS. Estimation of insulin secretion rates from C-peptide levels. Comparison of individual and standard kinetic parameters for C-peptide clearance. Diabetes. 1992;41(3):368-377. doi:10.2337/diabetes.41.3.368

45. Utzschneider KM, Prigeon RL, Tong J, et al. Within-subject variability of measures of beta cell function derived from a 2 h OGTT: implications for research studies. Diabetologia. 2007;50 (12):2516-2525. doi:10.1007/s00125-007-0819-5

46. Grunberger G, Qiang X, Li Z, et al. Molecular basis for the insulinomimetic effects of C-peptide. Diabetologia. 2001;44 (10):1247-1257. doi:10.1007/s001250100632

47. Anoop S, Misra A, Bhatt SP, Gulati S, Mahajan H. High fasting C-peptide levels and insulin resistance in non-lean \& non-obese (BMI $>19$ to $<25 \mathrm{~kg} / \mathrm{m}(2)$ ) Asian Indians with type 2 diabetes are independently associated with high intra-abdominal fat and liver span. Diabetes Metab Syndr. 2019;13:708-715.

48. Liu M, Ao L, Hu X, et al. Influence of blood glucose fluctuation, C-peptide level and conventional risk factors on carotid artery intima-media thickness in Chinese Han patients with type 2 diabetes mellitus. Eur J Med Res. 2019;24(1):13. doi:10.1186/s40001-019-0370-0

49. Pikkemaat M, Andersson T, Melander O, Chalmers J, Radholm K, Bengtsson Bostrom K. C-peptide predicts all-cause and cardiovascular death in a cohort of individuals with newly diagnosed type 2 diabetes. Skaraborg Diabetes Reg Diabetes Res Clin Pract. 2019;150:174-183. doi:10.1016/j.diabres.2019.03.014
50. Kim JD, Kang SJ, Lee MK, et al. C-Peptide-Based Index Is More Related to Incident Type 2 Diabetes in Non-Diabetic Subjects than Insulin-Based Index. Endocrinol Metab. 2016;31(2):320-327. doi:10.3803/EnM.2016.31.2.320

51. Postprandial SY. C-Peptide to Glucose Ratio as a Marker of beta Cell Function: implication for the Management of Type 2 Diabetes. Int J Mol Sci. 2016;17.

52. Meier JJ, Menge BA, Breuer TG, et al. Functional assessment of pancreatic beta-cell area in humans. Diabetes. 2009;58 (7):1595-1603. doi:10.2337/db08-1611

53. Binoux M. The IGF system in metabolism regulation. Diabete Metab. 1995;21:330-337.

54. Wittfooth S, Qin QP, Lund J, et al. Immunofluorometric point-of-care assays for the detection of acute coronary syndrome-related noncomplexed pregnancy-associated plasma protein A. Clin Chem. 2006;52 (9):1794-1801. doi:10.1373/clinchem.2006.070607

55. Hjortebjerg R. IGFBP-4 and PAPP-A in normal physiology and disease. Growth Hormone IGF Res. 2018;41:7-22. doi:10.1016/j. ghir.2018.05.002

\section{Publish your work in this journal}

Diabetes, Metabolic Syndrome and Obesity: Targets and Therapy is an international, peer-reviewed open-access journal committed to the rapid publication of the latest laboratory and clinical findings in the fields of diabetes, metabolic syndrome and obesity research. Original research, review, case reports, hypothesis formation, expert opinion and commentaries are all considered for publication. The manuscript management system is completely online and includes a very quick and fair peer-review system, which is all easy to use. Visit http://www.dovepress.com/testimonials.php to read real quotes from published authors. 